\title{
AVALIAÇÃO DA DIVERSIDADE GENÉTICA EM UMA POPULAÇÃO DE Eucalyptus spp. UTILIZANDO MARCADOR MICROSSATÉLITE (SSR).
}

\author{
Mayara Martins Aparecido ${ }^{1}$ \\ Alexandre Alves Missiaggia ${ }^{2}$ \\ Flávia Villaça Morais ${ }^{3}$
}

\begin{abstract}
Resumo: No melhoramento genético de espécies florestais a variabilidade genética constitui a matériaprima do programa sobre a qual são realizados os processos de seleção. Esse método visa selecionar os indivíduos de melhores procedências garantindo a obtenção de ganhos genéticos de forma continua. $O$ objetivo deste trabalho foi avaliar a diversidade genética existente em uma população de eucalipto da Fibria Celulose S.A utilizando marcadores microssatélites (SSR) que sejam informativos para esse tipo de estudo. Foram avaliados 75 indivíduos através de reações de PCR (Polymerase Chain Reaction), utilizando-se 9 primers seguidas de eletroforese em gel de agarose. O número de alelos encontrado para cada primer variou de 4 a 7 alelos. A heterozigosidade esperada teve uma média de 0,7 para a população avaliada. $A$ análise de discriminação realizada por este tipo de marcador possibilitou o agrupamento dos indivíduos em quatro grupos distintos. Os resultados obtidos demonstram que o uso de marcadores microssatélites (SSR) permitiu verificar a existência e quantificar a diversidade genética da população selecionada para este estudo.
\end{abstract}

Palavras-chave: Eucalyptus; Diversidade genética; SSR.

\footnotetext{
${ }^{1}$ Ciências Biológicas/Universidade do Vale do Paraíba, Brasil. E-mail: mayarama92@gmail.com.

2 Fibria Celulose S.A./Centro de Tecnologia, Brasil. E-mail: amissiaggia@fibria.com.br.

${ }^{3}$ Universidade do Vale do Paraíba/Instituto de Pesquisa e Desenvolvimento-IP\&D, Brasil. E-mail: flavia@univap.br.
} 